\title{
Analysis of Creative Thinking Ability of Primary School Department Student on Proposing Mathematics Problem
}

\author{
Nyamik Rahayu Sesanti ${ }^{1}$, Retno Marsitin ${ }^{2}$ \\ Kanjuruhan University \\ Malang Indonesia \\ 1nyamik@unikama.ac.id \\ 2mars.ayu@unikama.ac.id
}

\begin{abstract}
Mathematical creative thinking ability is important thing to be considered for prospective educators. Students will develop their Mathematical creative thinking if the teacher having understanding about mathematical creative thinking. Besides teacher should use suitable strategy and approach when they teach their students. Primary school education department students should be provided with mathematical critical thinking to raise their creativity and innovation in teaching learning process. The aim of this research is to describe the creativity of primary school education department students in proposing mathematical problem. This research used descriptive qualitative method since the researcher wanted to explore mathematical creative thinking of primary school department students in proposing mathematical problem. In analyzing data, the researcher identified mathematical questions made by primary school education department students using fluency, flexibility and novelty criteria. The findings showed that $76 \%$ students got their fluency, $68 \%$ students belongs to flexibility criteria and for novelty criteria only obtained by $15 \%$ students. It can be concluded that primary school education department student in creative level.
\end{abstract}

Keywords - Mathematical creative thinking, Primary school education department students

\section{INTRODUCTION}

The ability to think creative is important and must be considered for prospective educators. The ability to think creatively requires learners in. The development of creativity of learners and the ability to think creatively through creative activities in math lessons is very important in this regard. The ability to think creatively is also required by learners to have the ability to produce, manage, and utilize information to survive in an ever-changing, uncertain, and competitive live.

The ability to think creatively is necessary in math problem solving. Thoughts and creative ideas in formulating mathematical models, will help learners in solving math problems. Because the nature and characteristics of mathematics is logical,

systematic, critical and creative thinking. Thought and creative ideas will improve the smoothness of learners in completing mathematics. It will also involve more than one mathematical solution, even finding something new in mathematical problem solving. This is because creative thinking can also improve students' thinking ability to be flexible, fluent, and original[7].

Creative thoughts and ideas will emerge and develop in learners, if the process of learning mathematics in the classroom using the appropriate learning approach. The abilityn of mathematics creative thinking will also develop in learners, if educators have an understanding of mathematics creative thinking. Educators also need to use appropriate learning strategies or approaches in the classroom learning process.

Primary school education department students of University of Kanjuruhan Malang are students who are prepared to be educators. Therefore they have to be euipped withs creative thinking. Students must understand about the creative thinking ability of learners. Students also have to have skills in learning that increase learners creativity.

The improvement of the ability of mathematics creative thinking can be done with proposing mathematic problems. Students pose math problems in the form of making math problems that are able to measure learners creative thinking ability. Mathematical problems created should be able to measure the fluency, flexibility and novelty of the learners.

The process of fluency can be seen by giving more than one answer, idea, question, result or product and the ability to provide various ways or suggestions to do things to overcome a particular problem. In the process of flexibility can be seen 
from the producing ideas, answering question, and having different perpective in solving problem. Learners have the ability to change the way of approach or way of thinking and usually its emphasis on quality, usability and diversity of answers. Not only the number of answers given that determine the quality of a person, but also determined by the quality or quality of answers. In the novelty process generate outstanding ideas, rarely discover and unique. Usually learners generate ideas out of reality that exist or only exist on their imagination. Therefore, it is considered as unusul idea. It can also mean the ability in creating new things is not totallt new thing but it can be combined with the previous one

Siswono stated that creative thinking involves synthesizing ideas, building new ideas, determining their effectiveness and ability to make decisions and produce new products. Jonhson says that creative thinking that implies perseverance, personal discipline and attention involves mental activities such as asking questions, considering new information and unusual ideas with an open mind, relationships, especially between something similar, relate to one another freely, apply imagination to situations that generate new and different ideas, and pay attention to intuition.[1]

Mathematics creative thinking refers to a combination of logical and divergent thinking that is based on intuition but realizes its purpose Pehkonen (1997). Runco (in Kaufman et al., 2008: 17) defines divergent thinking as knowledge that leads in different directions. Divergent thinking focuses on flexibility, fluency, and novelty in solving math problems. William (in Munandar, 2009: 160-193) defines the characteristics of creative thinking ability including divergent thinking, namely (a) fluency, (b) flexibility , (c) originality, and (d) Detailing or elaboration. a) fluency

Children can provide more than one answer, idea, question, result or product and the ability to provide various ways or suggestions to do things to overcome a particular problem. b) Flexibility

Children can generate ideas, answers, variations, and have the ability to see a problem from different perspective. The child has the ability to change the way of approach or way of thinking and usually emphasizes the quality, usability and diversity of answers. Not only the number of answers given that determines the quality of a person, but also determined by the quality or quality of answers.

\section{c) Originality}

Children can produce extraordinary ideas, rarely encountered and unique. Usually children produce ideas that are out of reality that exist or only exist on their imagination. Therefore, it is considered as unusual idea. . It can also mean the ability in creating new things is not totallt new thing but it can be combined with the previous one

\section{d) Detailing or elaboration}

Children can develop an idea, product, or work to add or detail details of the object, idea, or situation so that it becomes more interesting.

Components of creative thinking in solving mathematical problems include fluency, flexibility, and novelty [2]. Fluency in solving mathematical problems is students ability to generate many solutions in solving mathematic problems. Flexibility in mathematical problem solving is the ability of students to solve problems in different ways or methods. Novelty in mathematical problem solving is the ability of students to produce many different and true solutions or find new solutions that are not commonly used by students with the same level of ability. According Siswono novelty is the highest position in creative thinking, beside flexibility and fluency [3]. Fluency according to English dictionary is "effortlessly smooth and rapid" it means that flueccy is easy, smooth and fast, Flexibility is "capable of responding" that is ability to respond, novelty is "something new or unusual" it can be said that novelty is something new and unusual problem solving given by the students.

For further studies creative thinking is defined as a mental process that a person uses to create a "new" idea or idea "fluently and flexibly". The idea in this case is the idea of solving mathematical problems. The ability to think creatively in this research only on the ability to think fluency, flexibility, and novelty.

Problem solving is the formulation of questions relating to the terms on the problem solved in order to search for alternative solutions or alternatives to relevant questions. Further, Silver states that problem-solving activity is usually used in three forms of mathematical cognitive activity, namely: (1) presolution posing, learners produce initial problems generated by the stimulus; (2) within solution posing, learners formulate a problem that can be solved; and (3) post solution posing, learners modify the completed problem condition to produce new questions[4].

Silver defines problem-solving as problem formulation or reformulation, occurring in complex problem-solving processes when learners redo or recreate a problem in some way to make it easier to find a solution. While Bonotto in Imam[8] defines the filing of mathematical problems as a process in which learners construct personal interpretations of concrete situations and formulate them as meaningful math problems. The task of proposing a problem can be given to learners with a variety of purposes, for example developing studets' 
mathematical thinking skillls, assisting students in solving problems or developing creative thinking.

Stoyanova and Ellerton in Imam[8] classify situations for problem solving into three situations: free problem posing situation, semi structured problem posing situation, structured problem posing situation. The description of each type will be explained as:

\section{Free issue posing situation}

In free issue posing situation, problems are made on the basis of everyday life situations. Assigned tasks can take the form of: "make a simple or complex problem", "make a problem you like". In this situation it is more effective in developing students' mathematical thinking. Problem situations can include: daily life situations, free issue submissions, student favored issues, problems for mathematical competition, written problems for students and issues built for fun. For example, Ellerton in Mardianata[9] introduced creative writing in mathematics by asking students to make math problems. Teacher asked learner to pose a difficult problem to be solved by his friend, asked the learner to write a letter to a friend. According to Ellerton the expression of mathematical ideas of learners through the creation of their own mathematical problems shows not only the understanding and level of development of their concepts, but also reflects their perception of the nature of mathematics. 2.Semi-structured problem posing situation

In this situation students are given an openended situation and are asked to explore it using their knowledge, skills, concepts and relationships of prior mathematical experience. The form of questions that can be given is an openended problem involving mathematical investigation activities, making a problem based on a given problem, making a problem with the same context as the given problem, making a problem related to a particular theorem, making a problem based on the image and the story given.

\section{Structured problem posing situation.}

In this situation students are asked to make a problem based on a known problem by altering known data or information. Learning problem formulation activity based on the completed problems by varying the conditions or objectives of the problem given. The problem solving activity can be done before, during, and after the problem solving. It is adjusted to the objectives to be achieved. According to Silver [4] problem solving is generally applied to three very different forms of mathematical cognitive activity:

a. Presolution posing (before solving problem) means tht generating the original problem ba on the given sitution or information. b. Within solution posing (during solving the problem), it means posing or formulating the problem being solved. Posing problems in this terms is intended as a simplification.

c. Post solusing posing (after solving the problem). It can be modifying or revising the objective or condition of a problem that has been resolved to produce a new problem. Several ways can be used to address the problem as follows: change the information or data in the original problem or sitution, but still maintain the data or information.

\section{METHOD}

This research used qualitative research approach. Judging from the type of problems discussed in this study, researchers used descriptive research type. Data analysis was done by identifying mathematical problems made by Primary school education department students, then adjusted to the criteria of fluency, flexibility and novelty.

Table 1. creativity indcator adapted from siswono[1]

\begin{tabular}{ll}
\hline Creativity & Problem posing \\
\hline Fluency & Students make many \\
& problems that can be solved. \\
& Students share the problem \\
& posed \\
\hline Fleksibility & Students pose problems that \\
can be solved in different \\
ways. \\
Students use the "what if \\
not" approach to pose a \\
problem. \\
\hline novelty & Students check out some of \\
& the issues then \\
filed a & new \\
& problem \\
\hline
\end{tabular}

\section{RESULT AND DISCUSSION}

Fluency in proposing mathematical problems in this research is that students can make more than two math problems that can be solved. Flexibility is that students can make more than two math problems that answer differently. Novelty in question is that students can make more than two different mathematical problems with other students and is a new problem.

In term of fluency, primary school education department students' creative thinking ability are varies. Researchers asked Primary school education department students to pose a mathematical problem in the form of open ended questions. Creative thinking on the category of fluency reached $76 \%$. Students can create more than two open ended math problems. Mathematical problems posed are easy to complete. 


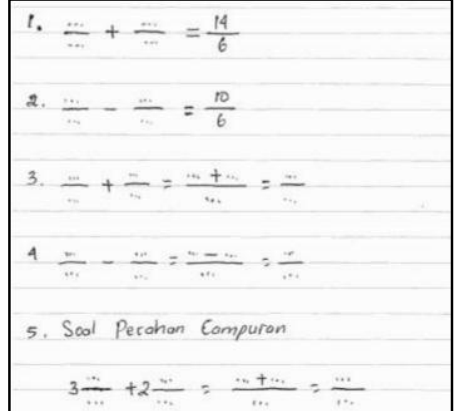

Fig.1 RF Working result

Based on RF working result, it indicate that he understand the assigned tasks, mathematical problems created by mathematical problem and open ended question type. The idea given is from mathematical procedural matters. RF has changed the procedural math problem to another condition.

In term of fexibility, primary school education department students students' creative thinking ability in the flexibility category reaches $68 \%$. Students can submit more than two math problems. The problem posed can be solved in different ways.

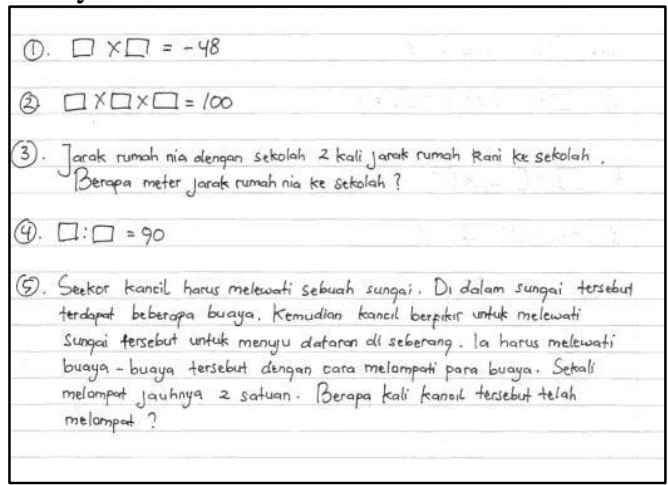

Fig.2 RW working result

According to the figure above, it can be seen that RW understand the assigned tasks, mathematical problems that he made was mathematical problems and open ended question type. The idea given of mathematics posed as a matter of open ended. RW sved the mathematical problem in the form of story problem. The good mathematical probelm alo showed from wa working result.

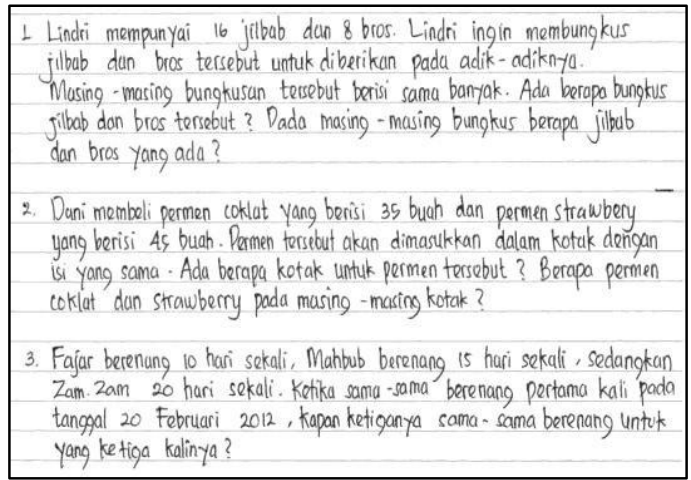

Fig.3 WA working result
From the figure above can be seen that WA actually understand with the assignment, but only two math problems are correct to be proposed. Mathematical problems created in the form of a story. WA turns regular routine into open ended questions.

In term of novelty, primary school education department students' creative thinking ability reaches $15 \%$. Students can create new and different math problems with other friends. Such as in the following figure

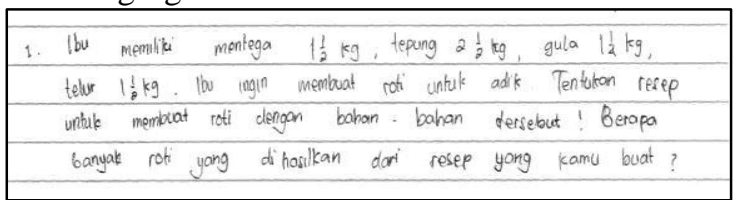

Fig.4 RK working result

Figure above give us example of students's work on novelty category. RK had made math problems in the story form. The recipe-making commands train students to think creatively in prescribing food recipes. This problem is different from other mathematical problems.

Students mistake inposing problem solving is also found in this research. It caused by lack of understanding in comprehending the understanding the assigned task and they did not understand with the open ended mathematical problem. For example the answer from one of the student initalled WL

\begin{tabular}{l|l|} 
2. & $(\quad) \times 6 \times 2=48$ \\
3. & $(-15) \times 20 \times() \times(-12) \times(-5)=480$ \\
×. & $(-20):(-4) \cdot()=5$ \\
5. ()$:()=90$
\end{tabular}

Fig.5 WL working result

WL answer is only the correct one. The other answers were not categorised math problems and open ended.

\section{CONCLUSION}

The ability to think creatively influenced by previous information about a particular concept. This ability also requires tudents sskills in applying the concept [5]. Joshua says that student creativity depends on certain mastery and knowledge gained previously. Creativity itself is the result of cognitive processes that work on the knowledge already stored in memory[6].

Thus it takes prior knowledge for Primary school education department students to create math problems. Students must also be skilled in managing their understanding so that they can be creative in making math problems. 


\section{REFERENCES}

[1] T. Yuli and E. Siswono, "Identifikasi Proses Berpikir Kreatif Siswa dalam Pengajuan Masalah ( Problem Posing ) Matematika Berpandu dengan Model Wallas dan Creative Problem Solving (CPS)," Bul. Pendidik. Mat., vol. Vol 6, no. 2, pp. 1-16, 2004.

[2] T. Y. E. Siswono, "Konferensi Nasional Matematika XII, Universitas Udayana , Denpasar, Bali. 23-27 July 2004," Konf. Nas. Mat. XII, Univ. Udayana, Denpasar, Bali, no. July, pp. 74-87, 2004. [3] T. Y. E. Siswono, “Leveling Students' Creative Thinking in Solving and Posing Mathematical Problem," J. Math. Educ., vol. 1, no. 1, pp. 17-40, 2010.

[4] E. A. Silver, "Fostering creativity through instruction rich in mathematical problem solving and problem posing," ZDM - Int. J. Math. Educ., vol. 29, no. 3, pp. 75-80, 1997.

[5] J. Harsant, "EDUCATION AND CREATIVITY: CHALK AND CHEESE? AN ANALYSIS OF THE KEY DEBATES IN THEORY, POLICY AND PRACTICE The dissertation is submitted in part fulfilment of the regulations for the BA Honours Degree in Education Studies and Sociology."

[6] B. Sriraman, "The Characteristics of Mathematical Creativity," Math. Educ., vol.

14, no. 1, pp. 19-34, 2004. 